\title{
ADSORPTION PROPERTIES OF AZADIRACHTA INDICA EXTRACT ON CORROSION OF ALUMINIUM IN 1.85 M HYDROCHLORIC ACID
}

\author{
Ajanaku K. O. ${ }^{{ }^{*} \text {, Aladesuyi O. }}{ }^{2}$, Ajanaku C.O. ${ }^{3}$, Adedapo E.A. ${ }^{4}$, Akinsiku A.A. ${ }^{5}$, Sodiya F.E. ${ }^{6}$, \\ *1,2,3,4,5 Department of Industrial Chemistry, Covenant University, Ota, Nigeria. P.M.B. 1023, Ota, Nigeria \\ ${ }^{6}$ Department of Chemistry, University of Ibadan, Oyo State, Nigeria
}

*Corresponding Author: -

kola.ajanaku@covenantuniversity.edu.ng

\begin{abstract}
: -
The crude extract of Azadirachta indica was used in the corrosion inhibition study of aluminium metal coupons in 1.85 $M$ hydrochloric acid environment by gasometric technique. The coupons were immersed in test solutions of uninhibited $1.85 \mathrm{M} \mathrm{HCl}$ and those containing extract concentrations of $10 \%, 20 \%, 30 \%, 40 \%$ and $50 \%(\mathrm{v} / \mathrm{v})$ at room temperature. The rate of the reaction was captured by monitoring the volume of hydrogen gas evolved as a result of the interaction. The inhibition efficiency of the extracts and the adsorption isotherm of the process were calculated using Frumkin, Freundlich, Langmuir and Temkin adsorption theories and the surface morphology studied using Scanning Electron Microscopy (SEM). It was observed that the plant extract retarded the acid induced corrosion of aluminium and the volume of hydrogen gas evolved reduced with increasing extract concentration. The adsorption studies revealed that Langmuir isotherm is the best model for the adsorption of Azadirachta indica $\left(R^{2}=0.999\right)$ on aluminium surface. This implied that the Azadirachta indica extracts with aluminium metal undergoes chemisorption.
\end{abstract}

Keywords: Inhibition, Corrosion, Adsorption, Aluminium, Azadirachta indica, morphological study.

\section{(c) $(\$)$ (i)}




\section{INTRODUCTION}

Metal interaction with environment is a process that cannot be disregarded when the issue of corrosion and its effect comes to play. The effect is seen when metal in the combined state tends to revert back to its most stable natural state on exposure to certain environmental conditions. The effect of corrosion process has drastically affected a number of industries resulting in loss and damages with huge deficit (Barbara and Robert, 2006; Rosliza, 2012).

The effect of corrosion on the aqueous environment of sea water, salt water and rain, can be felt when pipes corroded with toxic metals are allowed to sips into the environment thereby causing health complications to the living system as contained in the aqueous environment. Other causes can be hazardous, which may results in loss of capital, loss of equipment and alienation of workforce, fire and explosion etc. (Holsen et al., 1991). The ability to protect metallic materials especially those used in engineering becomes important and a number of ways have been deployed in controlling corrosion such as electroplating and use of inhibitors. These are substances added in small concentrations to corrosive media to decrease or prevent the reaction of the metal in the media (Chauhan and Gunasekaran, 2007). The inhibitors can be organic or inorganic, and most credible option is the use of natural inhibitors as an eco-friendly option. The synthetic inhibitors has heteroatom such as $\mathrm{O}, \mathrm{N}$, and $\mathrm{S}$ and multiple bonds in their molecules through which they become adsorbed on the metal preventing the metals from corroding, they are highly basic with high electron density which gives the characteristics of an inhibitor (James et al. 2009; 2011; Rani and Bharathi, 2012). However, investigation has shown that some of the synthetic and inorganic inhibitors are toxic causing kidney failure, liver failure, and mutation of the enzymes etc. (Singh et al., 2012).

Since synthetic inhibitors have been proven to have acute hazardous effect to human, therefore natural products have been scrupulously analyzed and found to be effective in prevention of corrosion. Plant extracts have been found to be ecofriendly, inexpensive and obtainable in large quantities (Ambish et al., 2010; Omotoso et al. 2012; Olusegun et al., 2013). The availability of organic compounds in the natural product such as tannin, saponins, and alkaloids give it its inhibitive traits (Abdel-Gaber et al., 2008; Ajanaku et al., 2012). A number of researchers are now attracted to the trend of using natural products as inhibitors. Kliskic et al., (2000) found that Rosemary leaves had an inhibiting effect on Al-Mg alloy corrosion in chloride solution. Amuradha et al., (2008) investigated the inhibition of carbon steel in low chloride media by an aqueous solution of Hibiscus rosa-sinensis Linn. The extraction of these natural products is also cheap and easy to accomplish.

Azadirachta indica (Neem) is an evergreen tree growing in almost every state of India where it has been used for centuries for medicinal purpose and pest management (Ermel, 1995). Neem kernels contain 30-50\% of oil and many active ingredients having antifeedant, growth-inhibiting, anti-oviposition and insecticidal activities (Schmutterer, 1995). Neem oil fatty acids comprise oleic, stearic, palmitic and linoleic acids, mainly used by the soap, pesticide and pharmaceutical industries. Therapeutically, its crude extracts from bark and leaves have been used in folk medicine to control diseases such as leprosy, intestinal helminthiasis and respiratory system (Prieto et al., 1999). Besides these uses, there are several other reports on the biological and pharmacological actions such as antiviral, antibacterial, antifungal, anti-inflammatory, antipyretic, antiseptic and antiparalitic uses (Prieto et al., 1999; Eshrat and Ali, 2002; Britto and Sheeba, 2011). The rationale for this work is to investigate the effect of the extract of Azadirachta indica on aluminium metal in $1.85 \mathrm{M} \mathrm{HCl}$ environment.

\section{Materials and Methods}

Preparation of Aluminium coupons

Rectangular specimen of the wrought Aluminium alloy of AA 2xxx were mechanically pressed cut into coupons of 24 $\mathrm{mm} \times 14 \mathrm{~mm}$ and $1 \mathrm{~mm}$ thickness using manual edge metal cutter. The coupons were examined to eradicate rough edges, which could influence the corrosion monitoring process. Surface treatment of the coupons was done by degreasing in ethanol and further drying in acetone and then stored in desiccator to avoid moisture absorption. The composition of the Aluminium samples was analyzed using optical emission spectrophotometer and the result were as follows:

Table 1: Composition of the Aluminium sample used for the study

\begin{tabular}{|l|l|}
\hline Elements & Wt. \% \\
\hline $\mathrm{Si}$ & 0.57 \\
\hline $\mathrm{Fe}$ & 1.18 \\
\hline $\mathrm{Mg}$ & 0.01 \\
\hline $\mathrm{Ti}$ & 0.11 \\
\hline $\mathrm{Sr}$ & 0.31 \\
\hline $\mathrm{Cu}$ & 0.01 \\
\hline $\mathrm{Pb}$ & 0.012 \\
\hline $\mathrm{Al}$ & 93.10 \\
\hline
\end{tabular}

\section{Extraction of Azadirachta indica leaves}

Leaves of Azadirachta indica were air dried at room temperature and crushed into powder. $10 \mathrm{~g}$ of the powder was refluxed with $200 \mathrm{~cm}^{3}$ of $1.85 \mathrm{M} \mathrm{HCl}$ solution for 2 (two) hours and left overnight before it was filtered. Extract concentration of $10 \%, 20 \%, 30 \%, 40 \%, 50 \%$ (v/v) was obtained through serial dilution using $1.85 \% \mathrm{HCl}$. The experimental set up (Figure 1) is similar in literature (Ajayi et al., 2011) and all reagents were of analar grade. 


\section{Corrosion inhibition using Gasometric method}

Gasometric (gas-volumetric) technique is a rapid and reliable means of ascertaining any perturbation by the inhibition with regard to gas evolution at the metal/corrodent inter-phase. Each of the specimens was dropped into the mylius cell containing $50 \mathrm{~cm}^{3}$ of the blank solution $(1.85 \mathrm{M} \mathrm{HCl})$ at room temperature and the volume of hydrogen $\left(\mathrm{H}_{2}\right)$ gas evolved per min interval was recorded. A volume/volume (v/v) dilution of 10\%, 20\%, 30\%, 40\%, 50\% was utilized, to study the inhibitive effect and the volume of $\mathrm{H}_{2}$ gas evolved per min interval was also recorded. At the end of each experiment of hydrogen evolution, the aluminium specimen was withdrawn from the mylius tube and weighed, in semblance with method used by Eddy et al., (2010). A graph of volume against time interval was carried out. The inhibition efficiency (I.E.) was then determined using equation 1 (Okafor et al., 2005).

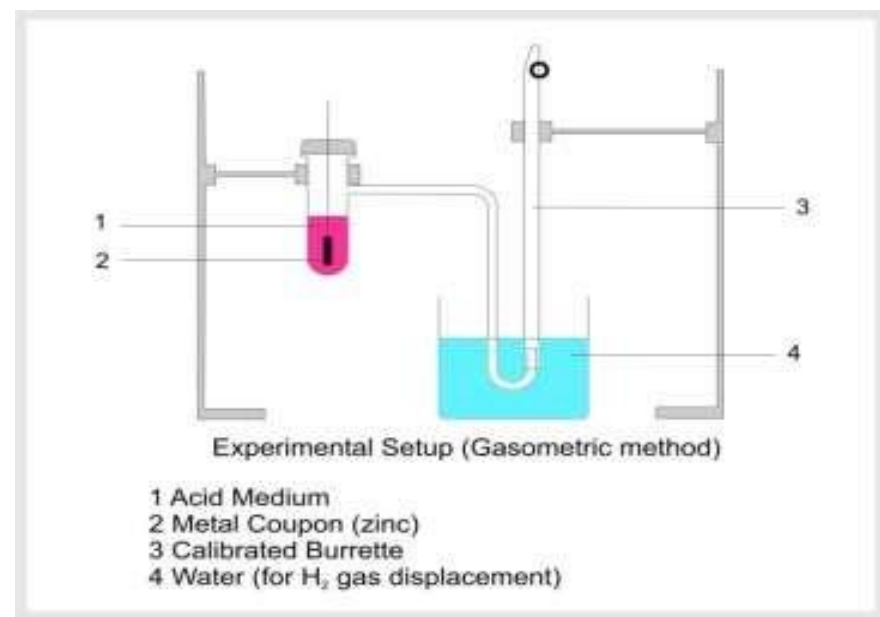

Figure 1: Experimental set up for gasometric method

$$
I . E(\%)=\frac{V_{H}-V_{H I}}{V_{H}} X 100 \ldots \ldots \ldots . . e q u .1
$$

$\mathrm{VH}=$ Volume of hydrogen evolved without inhibitor

$\mathrm{VHI}=$ Volume of hydrogen gas with inhibitor

Since the reaction of Aluminium with $\mathrm{HCl}$ gives off hydrogen gas as one of its products, it is easier to infer that the rate of reaction corresponds to the rate of corrosion damage of the aluminium in $\mathrm{HCl}$ and can also be monitored in the presence of Azaradichta indica extracts as inhibitor. However based on the assumption made in the literature, (Ajayi et al., 2011) the following relationships were also obtained. The basis for this is represented in equation 2

$$
\begin{aligned}
& \Delta V \alpha \Delta W \ldots \ldots \ldots \ldots \ldots . \text { equ. } 2 \\
& \frac{d \Delta V}{d t} \alpha \frac{d \Delta W}{d t} \\
& \text { but } \\
& \frac{R \alpha \mathrm{dW}_{\mathrm{m}}}{d t} \alpha \frac{d \Delta \mathrm{V}_{\mathrm{H}}}{d t} \ldots \ldots \ldots \ldots . . \text { equ. } 3
\end{aligned}
$$

Where

$\alpha=$ proportionality sign

$\Delta \mathrm{V}=$ Volume of hydrogen gas evolved

$\Delta \mathrm{W}=$ Metal weight loss due to corrosion

$\mathrm{R}=$ Corrosion rate

$\mathrm{t}=$ Time $(\mathrm{sec})$

Thus to determine Equation 3, it is important to develop a relationship between volume evolved and time of evolution. This was arrived by at a polynomial regression analysis of the volume of hydrogen gas against time leading to Equation 4 (Noor, 2007).

$$
\begin{gathered}
\mathrm{V}=\mathrm{c}+\mathrm{bt}+\mathrm{at}^{2} \ldots \ldots \ldots \ldots \ldots \ldots \text { equ. } 4 \\
R=\frac{d v}{d t}=\mathrm{b}+2 \mathrm{at} \ldots \ldots \ldots \ldots \ldots \text { equ. } 5
\end{gathered}
$$

Adapting Equation 4 and Equation 5 to the volume-time measurement for individual concentration and using the example for measurement relating to $50 \mathrm{~cm}^{3}$ concentration of Azadirachta indica extract in $1.85 \mathrm{M} \mathrm{HCl}$ the corrosion rate model is shown as:

$$
\mathrm{V}=0.325 \mathrm{t}^{2}-2.725 \mathrm{t}+1.375 d v
$$




$$
\frac{d v}{d t}=0.650 \mathrm{t}-2.725 \ldots \ldots \ldots \ldots . . . \text { equ. } 6
$$

The corrosion rate $K$, is derived from the second differential of $V_{\text {in }}$ as in $\mathrm{d}^{2} \mathrm{~V}_{\text {in }} / \mathrm{dt}^{2}= \pm \mathrm{C}$

$$
\Phi=\frac{I E}{100} \ldots \ldots \ldots \ldots \ldots \ldots . . . \text { equ. } 7
$$

Where $\Phi$ is surface coverage and I.E is Inhibition efficiency

\section{Results and Discussion \\ Inhibition properties of Azadirachta indica extract}

The free corrosion of the aluminium metal in $1.85 \mathrm{M} \mathrm{HCl}$ was characterized by rapid effervescence resulting for hydrogen evolution using blank (0\% extract) and also in the presence of the various extract concentrations (10\% - 50\%) for Azadirachta indica extract as shown in Figure 2.

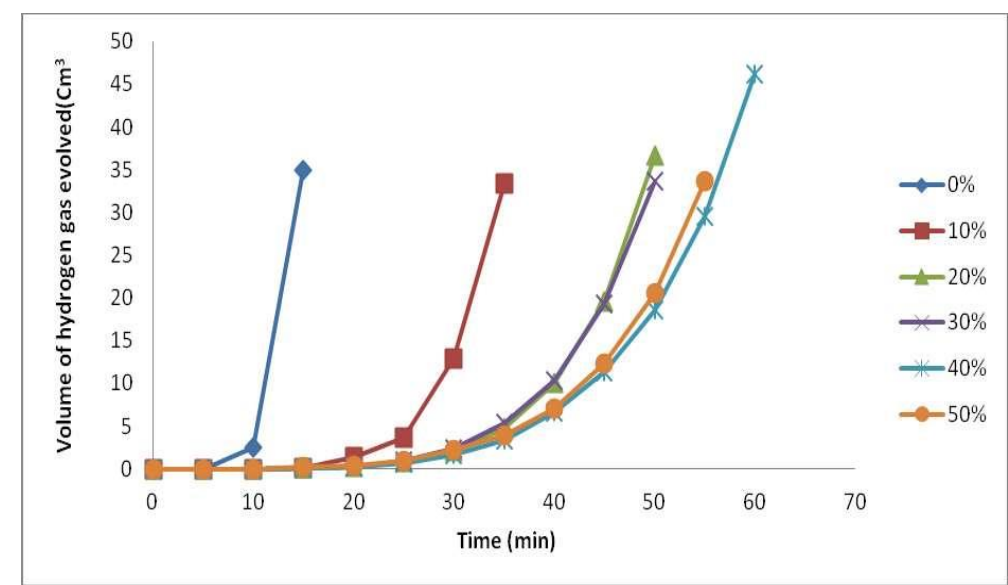

Figure 2: Variation of volume of hydrogen $\left(\mathrm{cm}^{3}\right)$ evolved with time $(\mathrm{min})$ of Aluminium coupons for different concentration of Azadirachta indica extract in $1.85 \mathrm{M} \mathrm{HCl}$ at room temperature.

The minimum regression value of 0.9154 was obtained for $10 \%(\mathrm{v} / \mathrm{v})$ and 0.9158 for $40 \%(\mathrm{v} / \mathrm{v})$ which indicated that the extract actually inhibits corrosion of aluminium in the acidic environment. Further reduction in the volume of hydrogen gas was observed as the extract concentration increased from $10 \%$ to $50 \% \mathrm{v} / \mathrm{v}$; suggestive that the inhibitive action was concentration dependent.

\section{Inhibitive efficiency of Azadirachta indica extract}

The plot of the inhibition efficiency against time of Azadirachta indica extract in $1.85 \mathrm{M} \mathrm{HCl}$ is shown in Figure 3 . This revealed that inhibition efficiency increased with extract concentration. All extract concentration has peak I.E (\%) values between 8 to 12 minutes hus indicating the period for optimization range. This follows the same pattern reported by Abiola (2007) and Ajanaku et al. (2012) in the study of the inhibitive effect of plant extracts on the corrosion of aluminium in acidic media. Azadirachta indica leaves have been reported to contain alkaloids, cyanogenic glycosides, flavanoids, phytates saponins and tannins (Nwaogu et al., 2007). Hence anti-corrosion activity of Azadirachta indica extract can be attributed to phytic acid which binds unto the cathodic sites on the metal surface. Tannin containing extracts are reported to contain varying inhibition efficiency and inhibition mechanism (Ehteram et al., 2008). However tannins had demonstrated that inhibitive tendency is a function of molecular properties (absolute electronegativity, absolute hardness and the electron donating ability) of its constituent molecules. This is accountable for the difference in inhibition efficiency observed for Azadirachta indica extract as indicated in Figure 3. This observation conforms to Matamalala et al., (2000) report of which observed that natural tannins exhibit better corrosion inhibition and better adherence to metallic substrates. 


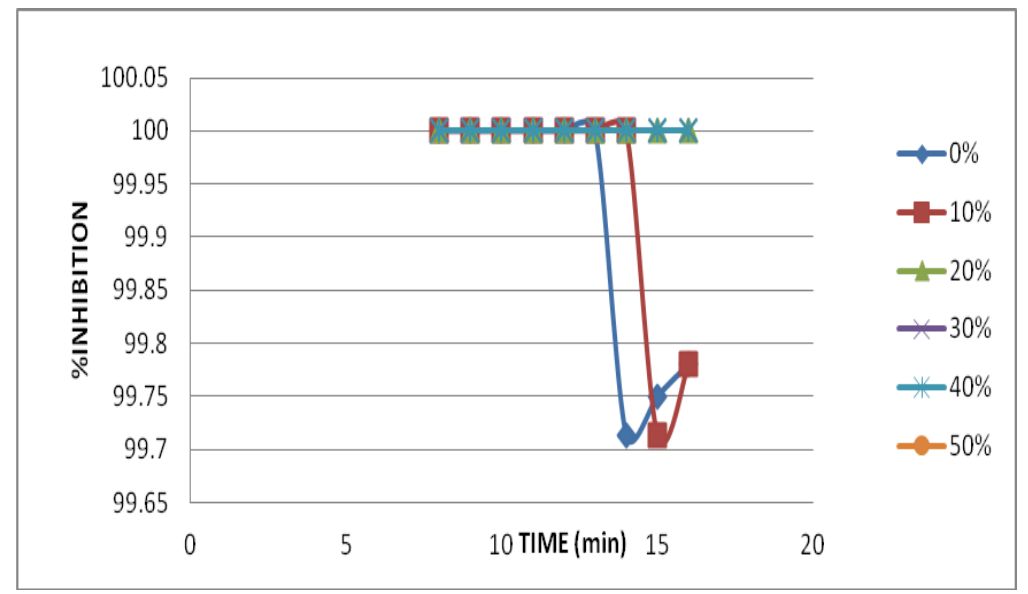

Figure 3: Percentage inhibition efficiency of varying concentration of Azadirachta indica extracts with time on Aluminium coupon in $1.85 \mathrm{M} \mathrm{HCl}$ solution at room temperature.

\section{Corrosion rate of Azadirachta indica extract on Aluminium}

Figure 4 shows a plot of corrosion rate against time for Azadirachta indica extract. It was observed that the rate of corrosion generally decreases in the presence of the extract. The $50 \% \mathrm{v} / \mathrm{v}$ sequence possesses the lowest corrosion rate, indicative that the inhibitive action of these extracts is concentration dependent. There may be argument as to the chemistry of Aluminium metal forming an oxide which may adsorbed alongside with the Azadirachta indica extract by making this less prone to the $\mathrm{HCl}$ interaction but it's been known that the presence of heteroatom fused benzene rings may bring about complexity in attributing the certainty of the inhibition. This argument was confirmatory of Li et al., 2014 in the inhibition study of steel in $\mathrm{HCl}$ and $\mathrm{H}_{2} \mathrm{SO}_{4}$ solutions using bamboo leaf extract.

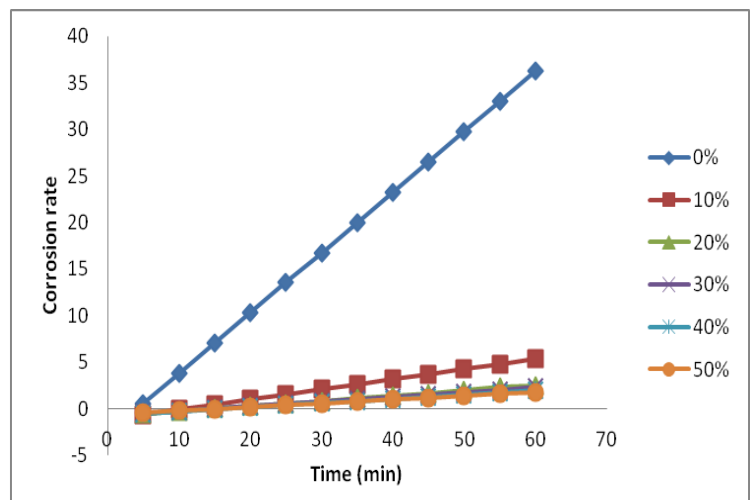

Fig. 4: Corrosion rate of varying concentrations of Azadirachta indica extract with time ( $\mathrm{min}$ ) on Aluminium coupon in $1.85 \mathrm{M} \mathrm{HCl}$ solutions at room temperature.

\section{Adsorption Isotherms}

One possible mechanism for corrosion inhibition using organic compounds is the adsorption of the inhibitor on the metal surface which blocks the active sites and thus prevents further corrosion of the metal from taking place. The adsorption route provides the information about the interaction among the adsorbed molecules themselves as well as with their metal surface whether it is physical adsorption or chemical adsorption.

The degree of surface coverage values for Azadirachta indica extract on the Aluminium metal was obtained from the hydrogen evolution measurement using equation 7 by assuming a direct relationship between surface coverage and inhibition efficiency. The results were fitted into adsorption isotherms of Frumkin, Freundlich, Langmuir and Temkin adsorption theories and the correlation coefficient $\left(\mathrm{R}^{2}\right)$ determined to check the best fitted isotherm (Table 2).

Table 2: Correlation coefficient of various adsorption isotherms obtained from Azadirachta indica extract at 15 minutes

\begin{tabular}{|l|l|}
\hline Adsorption & $\mathbf{R}^{\mathbf{2}}$ \\
\hline Temkin & 0.3161 \\
\hline Frumkin & 0.882 \\
\hline Freundlich & 0.9471 \\
\hline Langmuir & 0.9999 \\
\hline
\end{tabular}

The unity value of correlation coefficient obtained in the Langmuir isotherm is an indication that the adsorption of the extract onto aluminium surface best fits into the theory of Langmuir isotherm (Figure 5). This characterizes 
chemisorptions of the adsorbed species which is expected to have a correlation coefficient of unity in which the monolayer of the extract get attached to metal surface without lateral interaction between the adsorbed species. The observed result of the study shows that Azadirachta indica extract inhibit the acid induced corrosion of aluminium by virtue of adsorption on its component onto the metal surface.

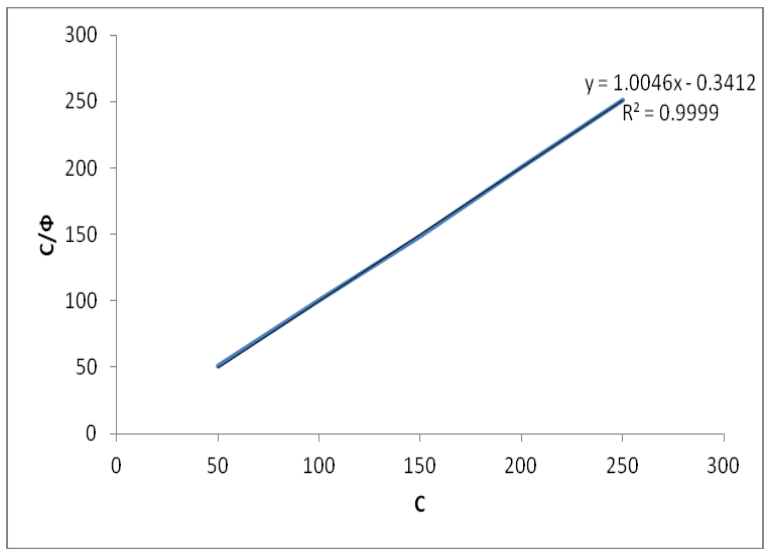

Figure 5: Langmuir adsorption plot for aluminium corrosion in Azadirachta indica extract in $1.85 \mathrm{M}$ at $15 \mathrm{~min}$.

\section{Surface Morphological Studies}

The surface morphology of the aluminum metal was studied using Carl Zeiss Sigma Field Emission Scanning

Electron Microscope and the images at $10 \mu \mathrm{m}$ of the aluminium surfaces at unhibited $(0 \%)$ and inhibited $(10 \% ; 30 \%$ and $50 \% \mathrm{v} / \mathrm{v}$ ) are shown in Figure 6 . The examination of fine structure of cells and the topographical information makes the usefulness of SEM pictures relevant in the study of corrosion prevention on metal surfaces. This helps in examining surface contaminations, provides qualitative chemical analyses and identifies crystalline structures. It was observed that the structural distinctive of the aluminium metal increases with the Azadirachta indica extract concentrations with a rapidly oxidized surface in the unhibited (A) to a glinting effect in the $50 \%$ inhibited (D) and partially luminous in the $30 \%$ (C). The morphology of B designated $10 \%$ concentration is not enough to effect inhibition. This cannot be fully ascertained because there is inclination of strong bond interaction at the surface of Aluminium, which may prevent relative sliding motion along the grain boundary when studied in acidic environment with inhibition thereby promoting embrittlement of the Aluminium alloy.

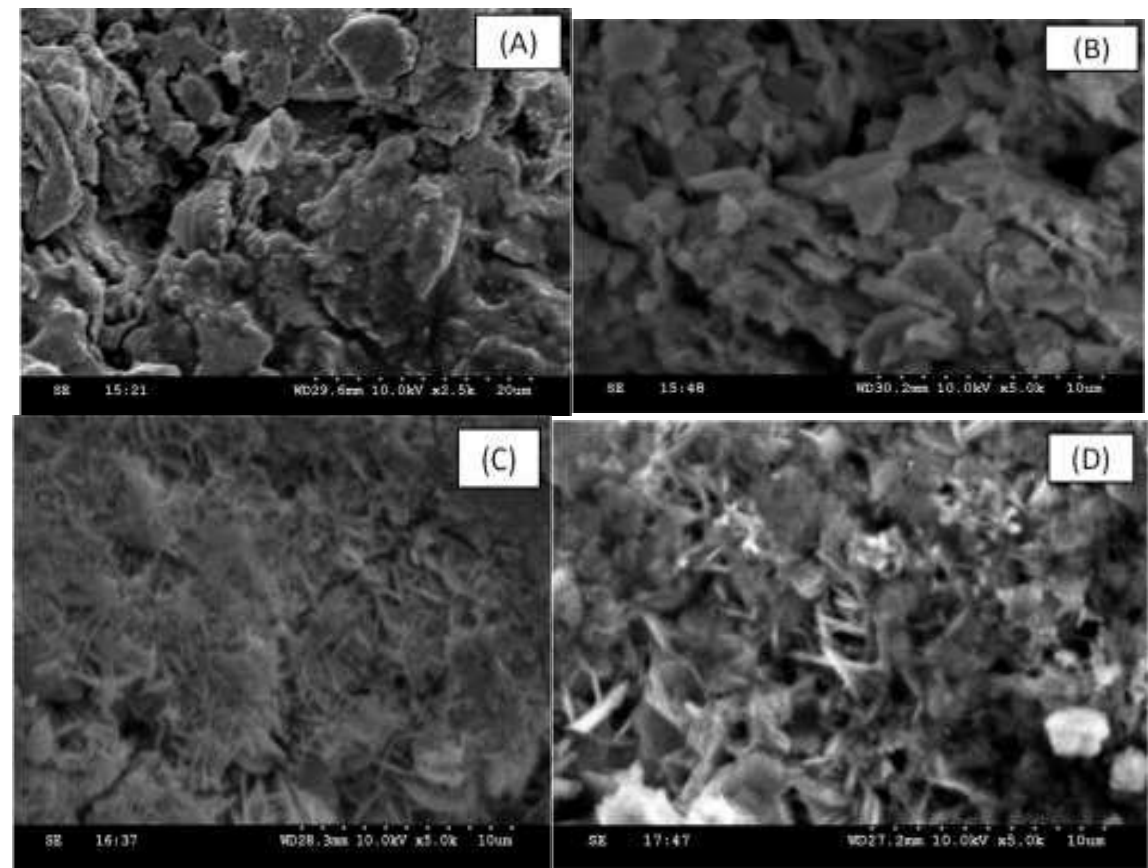

Figure 6: SEM images of aluminium coupons in 0\% (A); 10\% (B); 30\% (C) and 50\%

(D) Azadirachta indica leaf extract in $1.85 \mathrm{M} \mathrm{HCl}$ solution

\section{Conclusion}

The use of crude extract of Azadirachta indica as an inhibitor for Aluminium metal has been investigated in $1.85 \mathrm{M} \mathrm{HCl}$ and has been found effective. The inhibition efficiency of the extract increases in concentration of the inhibitor in which optimum inhibition concentration observed was $50 \% \mathrm{v} / \mathrm{v}$ of the Azadirachta indica extract. This is mainly due to the photochemical constituents of the extract on the metal surface thereby blocking its active sites by phenomenon of chemical 
adsorption. The morphological images as well as the adsorption isotherm study implies chemisorption pathway in the inhibition process.

\section{Reference}

[1].Abdel-Gaber A.M., Khamis E., Abo-Eldahab E., Adeel, S. (2008) Inhibition of aluminium corrosion in alkaline solution using natural compounds. Material Chemistry and Physics. 109: 297-305.

[2].Abiola O. K. (2007). Organic corrosion inhibitor for steel and aluminium in acid systems. Nova science publishers. ISBN 978-1-60021-733-3.

[3].Ajanaku, K.O., Ajanaku, C. O., Akinsiku A. A., Falomo A., Edobor-Osoh A. and John, M.O. (2012) Ecofriendly Impact of Vernonia amygdalina as corrosion inhibitor on aluminium in acidic media. Chemistry Journal. 2(4): 153157.

[4].Ajayi O. O., Omotosho O. A., Ajanaku K. O. and Olawore B. O. (2011) Degradation study of Aluminium alloy in 2M hydrochloric acid in the presence of Chromolaena odorata. Journal of Engineering and Applied Science, 6(1): 10-17.

[5].Ambish S., Singh V. K., Quaraishi M. A. (2010) Aqueous extract of Kalmeigh (Andrographis paniculata) leaves as green inhibitors for mild steel in hydrochloric acid solution. International Journal of Corrosion, 2010: 1-10.

[6].Anuradha K., Vimala R., Narayanasamy B., Selvi J. A., Rajendran S. (2008) Corrosion inhibition of carbon steel in low chloride media by an aqueous extract of Hibiscus rosa-sinensis Linn. Chemical Engineering Communications, 195(3): 352-366.

[7].Barbara S., Robert K. (2006) What is corrosion? The electrochemical society interface, 6: 24-26.

[8].Britto A.J., Sheeba D.H., (2011) Azadiracta indica juss - a potential antimicrobial agent. International Journal of Applied Biological and Pharmaceutical Technology. 4550-4557.

[9].Chauhan L. R., Gunasekaran G. (2007) Corrosion inhibition of mild steel by plant extract in dilute $\mathrm{HCl}$ medium, Corrosion Science, 49(3): 1143-1161.

[10]. Ehteram A., Noor A. H., Al-Moubaraki (2008) Corrosion behavior of mild steel in hydrochloric acid solutions. International Journal of Electrochemical Science, 3: 806-818.

[11]. Ermel K. 1995. Azadirachtin content of neem seed kernels from different regions of the world. In The Neem Tree, Schmutterer H (Ed); 89-92.

[12]. Eshrat H., Ali M. (2002) Using traditional Indian anti-diabetic plant Azadirachta Indica. Indian Journal of Clinical Biochemistry, 17: 115-123.

[13]. Holsen T. M., Park, J. K., Bontoux L., Jenkins D., Selleck, R.E., (1991) The Effect of Soils on the Permeation of Plastic Pipes by Organic Chemicals, Journal AWWA, 83(11): 85-91.

[14]. James O.O., Ajanaku K.O., Ogunniran K.O., Ajani O.O., Siyanbola T.O. and John M.O., (2011) Adsorption Behaviour of Pyrazolo [3, 4-b] Pyridine on Corrosion of Stainless Steel in HCl Solutions, Trends in Applied Sciences Research. 6(8): 910-917. DOI: 10.3923/tasr.2011.

[15]. James, O.O., Ajanaku, K.O., Ajani, O.O., Ogunniran, K.O. and John, M.O. (2009) Adsorption behaviour of [(4hydroxy-6-methyl-2-oxo-2H-pyran-3-yl)-(4-methoxy-phenylmethyl]-urea on stainless steel in phosphoric media, Portugaliae Electrochimica Acta. 27(5): 591 - 598

[16]. Kliskic M., Radoservic J., Gudic S., Katalinic V. (2000) Aqueous extracts of Rosmarinus offinalis Linn. as inhibitor of Al-Mg alloy corrosion in chloride solution, Journal of Applied Electrochemistry, 30(7): 823-830

[17]. Li X., Deng S., Fu H. (2014) Inhibition of the corrosion of steel in $\mathrm{HCl}, \mathrm{H}_{2} \mathrm{SO}_{4}$ solutions by bamboo leaf extract, Corros. Sci. 62: 163-175.

[18]. Matamalaa G., Smelterb W., Droguetta G. (2000) Comparison of steel anticorrosive protection formulated with natural tannins extracted from acacia and from pine bark, Corrosion Science, 42(8): 1351-1362.

[19]. Noor E. A. (2007) Temperature effects on the corrosion inhibition of mild steel in acidic solutions by aqueous extract of Fenugreek leaves. International Journal of Electrochemistry Science, 3: 996-1017.

[20]. Nwaogu L.A., Ojiako O.A., Ujowundu C.O. (2007) Studies on the Nutritional and Phytochemical composition of Asystasis gangetica leaves, J. Med. Pharm. Sci., 3(2): 50-53.

[21]. Okafor P.C., Ekpe U. J., Ebenso E. E., Umoren E. M., Leizou K. E. (2005) Inhibition of mild steel corrosion in acidic medium by Allum savitum Extract. Bulletin of Electrochemistry, 21(8): 347-352.

[22]. Olusegun S. J., Adeiza B. A., Ikeke K. I., Bodunrin M. O. (2013) Jastropha Curas leaves as corrosion inhibitors for mild steel in 1M hydrochloric acid. Journal of Emerging Trends in Engineering and Applied Sciences, 4(1): 138143.

[23]. Omotosho, O.A., Ajayi, O.O, Ajanaku, K.O., Ifepe, V.O. (2012) Environment Induced Failure of Mild Steel in 2 M Sulphuric acid using Chromolaena odorata. J. Mater. Environ. Sci. 3(1):66-75.

[24]. Prieto P., Pineda M., Aguilar M. (1999) Activity of a standardized neem (Azadirachta Indica) seed extract on the rodent malaria parasite plasmodium berghei. Analytical Biochemistry, 269: 337-341.

[25]. Rani B.E.A., Bharathi B. J. B. (2012) Green Inhibitors for Corrosion Protection of Metals and Alloys: An Overview. International Journal of Corrosion 2012: 1-15

[26]. Schmutterer H. 1995. Insecta, insects In: The Neem Tree, Schmutterer H (ed). VCH Weinheim; 167-365.

[27]. Singh A., Ebenso E. E., Qurashi M. A. (2012) Corrosion Inhibition of carbon steel in HCl solution by some plant extracts. International Journal of corrosion, 2012: pp. 1-20. 